\title{
Increased Nitrogen Loading Boosts Summer Phytoplankton Growth by Alterations in Resource and Zooplankton Control: A Mesocosm Study
}

\author{
$\mathrm{Hu} \mathrm{He}^{1 *}$, Kunquan Chen ${ }^{1}$, Yingxun $\mathrm{Du}^{1}{ }^{1}$ Kuanyi $\mathrm{Li}^{1,2}$, Zhengwen Liu $^{1,2,3}$, Erik Jeppesen ${ }^{2,4,5,6}$ \\ and Martin Søndergaard ${ }^{2,4}$ \\ 'State Key Laboratory of Lake Science and Environment, Nanjing Institute of Geography and Limnology, Chinese Academy of \\ Sciences, Nanjing, China, ${ }^{2}$ Sino-Danish Centre for Education and Research, Beijing, China, ${ }^{3}$ Department of Ecology and Institute \\ of Hydrobiology, Jinan University, Guangzhou, China, ${ }^{4}$ Department of Ecoscience, Aarhus University, Silkeborg, Denmark, \\ ${ }^{5}$ Limnology Laboratory, Department of Biological Sciences and Centre for Ecosystem Research and Implementation, Middle East \\ Technical University, Ankara, Turkey, ${ }^{6}$ Institute of Marine Sciences, Middle East Technical University, Mersin, Turkey
}

OPEN ACCESS

Edited by:

Vinicius Fortes Farjalla, Federal University of Rio de Janeiro,

Brazil

Reviewed by:

Nicolás Vidal Carcavallo, Universidad de la República, Uruguay Rayanne Setubal, Federal University of Rio de Janeiro,

Brazil

*Correspondence:

$\mathrm{Hu} \mathrm{He}$

hehu@niglas.ac.cn

Specialty section:

This article was submitted to

Freshwater Science,

a section of the journal

Frontiers in Environmental Science

Received: 07 September 2021

Accepted: 12 November 2021

Published: 01 December 2021

Citation:

He H, Chen K, Du Y, Li K, Liu Z, Jeppesen $E$ and Søndergaard $M$ (2021) Increased Nitrogen Loading

Boosts Summer Phytoplankton Growth by Alterations in Resource and Zooplankton Control: A Mesocosm Study.

Front. Environ. Sci. 9:772314. doi: 10.3389/fenvs.2021.772314
The effectiveness of controlling nitrogen $(\mathrm{N})$ to manage eutrophication of aquatic ecosystems remains debated. To understand the mechanisms behind phytoplankton growth in shallow lakes (resource and grazing effects) under contrasting $\mathrm{N}$ loading scenarios, we conducted a 70days mesocosm experiment in summer. The mesocosms contain natural plankton communities deriving from a 10-cm layer of lake sediment and $450 \mathrm{~L}$ of lake water. We also added two juvenile crucian carp (Carassius carassius) in each mesocosm to simulate presence of the prevailing omni-benthivorous fish in subtropical lakes. Our results showed that $\mathrm{N}$ addition increased not only water $\mathrm{N}$ levels but also total phosphorus (TP) concentrations, which together elevated the phytoplankton biomass and caused strong dominance of cyanobacteria. Addition of $\mathrm{N}$ significantly lowered the herbivorous zooplankton to phytoplankton biomass ratio and promoted the phytoplankton yield per nutrient (Chl-a: TP or Chl-a: TN ratio), indicating that summer $\mathrm{N}$ addition likely also favored phytoplankton growth through reduced grazing by zooplankton. Accordingly, our study indicates that summer $\mathrm{N}$ loading may boost eutrophication via both changes in resource and grazing control in shallow lakes. Thus, alleviation of eutrophication in shallow eutrophic lakes requires a strategic approach to control both nutrients ( $\mathrm{N}$ and $\mathrm{P}$ ) appropriately.

Keywords: eutrophication, sediment $\mathrm{P}$ release, zooplankton-cyanobacteria interaction, N:P ratio, mesocosm

\section{INTRODUCTION}

Nitrogen $(\mathrm{N})$ and phosphorus $(\mathrm{P})$ are key limiting factors determining autotroph growth in both terrestrial and aquatic ecosystems (Elser et al., 2007; Conley et al., 2009). The N:P ratio of reactive $\mathrm{N}$ and $\mathrm{P}$ anthropogenic inputs to the biosphere has dramatically increased during the past half century, inducing significant alterations in the organisms and ecosystems of Earth (Peñulas et al., 2012; Peñulas et al., 2013; Tong et al., 2020).

In shallow eutrophic lakes, in-lake TN:TP ratios are often low in summer due to the high denitrification and strong P release at high temperatures (Xu et al., 2010; Xu et al., 2021; Søndergaard 


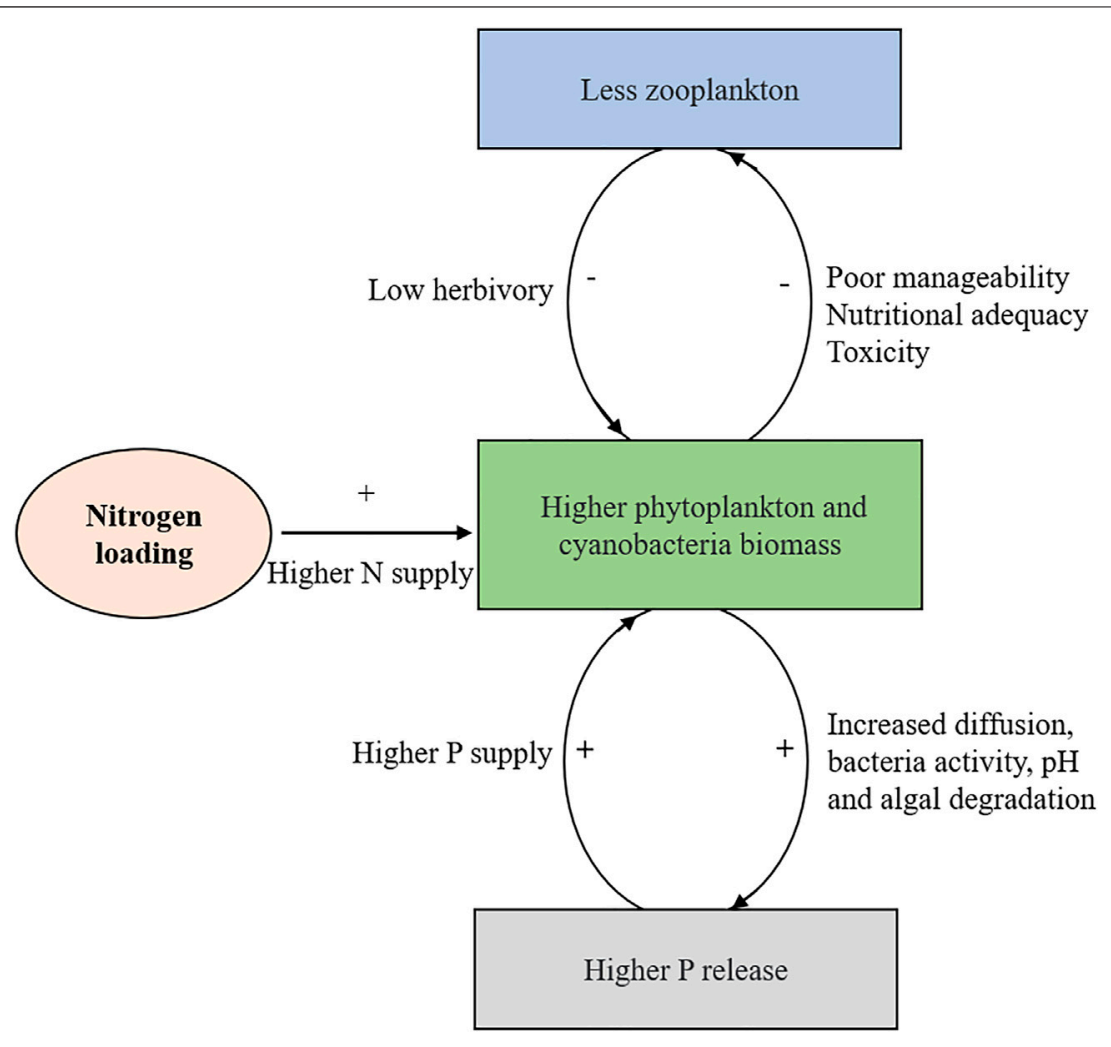

FIGURE 1 | Conceptual model of two feedback loops showing how nitrogen $(\mathrm{N})$ loading boosts summer eutrophication in shallow lakes. Firstly, the addition of $\mathrm{N}$ mitigates $\mathrm{N}$ deficiency in summer, which increases algal biomass and subsequently causes higher $\mathrm{P}$ release from sediments via a series of mechanisms such as increased diffusion and $\mathrm{pH}$. In turn, the new $\mathrm{P}$, together with external $\mathrm{N}$ loading, snowballs the phytoplankton biomass and thereby creates a positive feedback. Secondly, N addition may also increase the dominance of toxic, filamentous, or colonial cyanobacteria in eutrophic lakes, which expectedly reduces the efficiency of zooplankton herbivory due to poor manageability and nutrition value and high toxicity. Also, the decline in grazing control favors phytoplankton growth.

et al., 2013; Søndergaard et al., 2017; Shatwell and Köhler, 2019). From a resource availability perspective, excess $\mathrm{N}$ loading could directly increase the summer phytoplankton biomass via alleviation of temporal $\mathrm{N}$ deficiency, and this has been confirmed by numerous bioassays and mesocosm experiments (Xu et al., 2010; He et al., 2015; Kolzau et al., 2018). Nitrogen loading may also influence the internal $\mathrm{P}$ loading via feedback mechanisms between phytoplankton blooms and sediment $\mathrm{P}$ release (Xie et al., 2003; Gao et al., 2014; Chen et al., 2018). That is, a higher phytoplankton biomass due to summer $\mathrm{N}$ enrichment augments the $\mathrm{P}$ release from $\mathrm{P}$-rich sediments via various mechanisms including increasing diffusion, bacteria activity, $\mathrm{pH}$, and likely also degradation of settled algae (Xie et al., 2003; Gao et al., 2014; Chen et al., 2018; Ma et al., 2018; Ma et al., 2021). This released $P$, in turn, hinders a change of the system towards $\mathrm{P}$ limitation at persistent external $\mathrm{N}$ loading and, therefore, it creates a positive feedback loop benefitting phytoplankton growth (Figure 1). Nonetheless, high doses of nitrate, may also prevent $P$ release by improving oxidation of the sediment in shallow lakes (Andersen, 1982; Boström and Pettersson, 1982). For instance, a long-term investigation of 22 Danish shallow lakes revealed absence of $\mathrm{P}$ release if in-lake nitrate concentrations exceeded about $0.5 \mathrm{mg} \mathrm{L}^{-1}$ (Andersen, 1982). However, this pattern was not supported in studies of four Danish shallow eutrophic lakes where summer nitrate additions increased the $\mathrm{P}$ release from the sediment (Jensen and Andersen, 1992). Thus, the dual effect of oxidized nitrogen on sediment $\mathrm{P}$ release makes prediction of the effects of summer $\mathrm{N}$ loading in shallow lakes uncertain.

Excess $\mathrm{N}$ loading may also favor phytoplankton growth via reducing the fitness and biomass of herbivorous zooplankton (Trommer et al., 2017; Lorenz et al., 2019). For instance, mesocosm experiments found that $\mathrm{N}$ addition caused stoichiometric shifts in the biomass of primary producers towards higher N:P and C:P ratios, which lowered cladoceran and total zooplankton biomasses but favored the dominance of rotifers (Lorenz et al., 2019). In shallow lakes, although P has traditionally been considered the primary nutrient causing harmful cyanobacterial blooms, recent findings from laboratory studies and lakes throughout the world demonstrate that $\mathrm{N}$ can be important in controlling the timing, density, and toxicity of some nondiazotrophic cyanobacterial blooms (reviewed by Gobler et al., 2016). Beaulieu et al. (2013) assessed cyanobacteria blooms in 1,147 lakes and reservoirs with differing trophic status across the U.S. and found that the best predictors of these events were TN and water temperature. Multi-year observations from western Lake Erie in United States demonstrate that microcystin concentrations peak in parallel with inorganic $\mathrm{N}$ concentrations and are significantly lower 
TABLE 1 | Best results of the generalized linear mixed model using the function glmmTMB from the R package glmmTMB v1.0.2.1 (Brooks et al., 2017).

\begin{tabular}{|c|c|c|c|c|c|}
\hline & Coefficient & Estimate & SE & z-value & $\boldsymbol{P}$ \\
\hline \multirow[t]{2}{*}{$\mathrm{TN}\left(\mathrm{mg} \mathrm{L}^{-1}\right)$} & Intercept & -0.255 & 0.135 & -1.891 & 0.059 \\
\hline & $\mathrm{N}$ addition & 0.955 & 0.106 & 8.988 & $<0.001$ \\
\hline \multirow[t]{2}{*}{$\mathrm{TP}\left(\mathrm{mg} \mathrm{L}^{-1}\right)$} & Intercept & -2.957 & 0.191 & -15.484 & $<0.001$ \\
\hline & $\mathrm{N}$ addition & 0.994 & 0.126 & 7.919 & $<0.001$ \\
\hline \multirow[t]{2}{*}{ DTN $\left(m g L^{-1}\right)$} & Intercept & -0.867 & 0.102 & -8.474 & $<0.001$ \\
\hline & $\mathrm{N}$ addition & 0.566 & 0.114 & 4.974 & $<0.001$ \\
\hline \multirow[t]{2}{*}{$\mathrm{DTP}\left(\mathrm{mg} \mathrm{L}^{-1}\right)$} & Intercept & -3.920 & 0.105 & -37.470 & $<0.001$ \\
\hline & $\mathrm{N}$ addition & 0.213 & 0.113 & 1.890 & 0.059 \\
\hline \multirow[t]{2}{*}{$\mathrm{pH}$} & Intercept & 2.161 & 0.007 & 296.260 & $<0.001$ \\
\hline & $\mathrm{N}$ addition & 0.049 & 0.006 & 8.050 & $<0.001$ \\
\hline \multirow[t]{2}{*}{ DTP: TP } & Intercept & -1.075 & 0.188 & -5.698 & $<0.001$ \\
\hline & $\mathrm{N}$ addition & -0.643 & 0.279 & -2.303 & 0.021 \\
\hline TN: TP & Intercept & 2.665 & 0.051 & 51.980 & $<0.001$ \\
\hline PN: PP & Intercept & -0.058 & 1.129 & -0.052 & 0.959 \\
\hline \multirow[t]{2}{*}{$\mathrm{DO}\left(\mathrm{mg} \mathrm{L}^{-1}\right)$} & Intercept & 1.701 & 0.057 & 29.907 & $<0.001$ \\
\hline & $\mathrm{N}$ addition & 0.183 & 0.063 & 2.914 & 0.004 \\
\hline \multirow{2}{*}{ TSS $\left(\mathrm{mg} \mathrm{L}^{-1}\right)$} & Intercept & 3.053 & 0.194 & 15.774 & $<0.001$ \\
\hline & $\mathrm{N}$ addition & 0.552 & 0.116 & 4.744 & $<0.001$ \\
\hline \multirow[t]{2}{*}{ ISS $\left(\mathrm{mg} \mathrm{L}^{-1}\right)$} & Intercept & 2.687 & 0.266 & 10.102 & $<0.001$ \\
\hline & $\mathrm{N}$ addition & 0.358 & 0.142 & 2.519 & 0.012 \\
\hline \multirow[t]{2}{*}{ OSS $\left(\mathrm{mg} \mathrm{L}^{-1}\right)$} & Intercept & 1.817 & 0.169 & 10.70 & $<0.001$ \\
\hline & $\mathrm{N}$ addition & 0.937 & 0.175 & 5.36 & $<0.001$ \\
\hline \multirow[t]{2}{*}{ Chl-a $\left(\mu g L^{-1}\right)$} & Intercept & 2.407 & 0.599 & 4.015 & $<0.001$ \\
\hline & $\mathrm{N}$ addition & 2.146 & 0.540 & 3.976 & $<0.001$ \\
\hline Cladoceran biomass ( $\mu \mathrm{g} \mathrm{DW} \mathrm{L^{-1 } )}$ & Intercept & -0.639 & 1.534 & -0.416 & 0.677 \\
\hline Copepod biomass ( $\mu \mathrm{g}$ DW L L ${ }^{-1}$ ) & Intercept & 5.725 & 0.113 & 50.660 & $<0.001$ \\
\hline \multirow[t]{2}{*}{ Rotifer biomass $\left(\mu \mathrm{g} \mathrm{DW} \mathrm{L}{ }^{-1}\right)$} & Intercept & 0.808 & 0.677 & 1.193 & 0.233 \\
\hline & $\mathrm{N}$ addition & 1.162 & 0.453 & 2.565 & 0.01 \\
\hline Zooplankton biomass ( $\mu \mathrm{g} \mathrm{DW} \mathrm{L}^{-1}$ ) & Intercept & 5.759 & 0.109 & 52.81 & $<0.001$ \\
\hline Herbivorous zooplankton biomass ( $\mu \mathrm{g} \mathrm{DW} \mathrm{L}^{-1}$ ) & Intercept & 4.371 & 0.395 & 11.06 & $<0.001$ \\
\hline Zooplankton body mass ( $\mu \mathrm{g} \mathrm{DW}$ ind $^{-1}$ ) & Intercept & 0.452 & 0.092 & -4.937 & $<0.001$ \\
\hline Cladocerans: Copepods & Intercept & -5.709 & 1.408 & -4.055 & $<0.001$ \\
\hline \multirow[t]{2}{*}{ Zooplankton: Chl-a } & Intercept & 2.263 & 0.944 & 2.397 & 0.017 \\
\hline & $\mathrm{N}$ addition & 2.428 & 0.876 & 2.771 & 0.006 \\
\hline \multirow[t]{2}{*}{ Herbivorous zooplankton: Chl-a } & Intercept & 1.338 & 0.587 & 2.279 & 0.023 \\
\hline & $\mathrm{N}$ addition & -2.010 & 1.023 & -1.964 & 0.045 \\
\hline \multirow[t]{2}{*}{ Chl-a: TP } & Intercept & -1.465 & 0.208 & -7.046 & $<0.001$ \\
\hline & $\mathrm{N}$ addition & 1.053 & 0.148 & 7.085 & $<0.001$ \\
\hline \multirow[t]{2}{*}{ Chl-a: TN } & Intercept & -3.955 & 0.215 & -18.388 & $<0.001$ \\
\hline & $\mathrm{N}$ addition & 0.899 & 0.173 & 5.192 & $<0.001$ \\
\hline
\end{tabular}

Note: All data were modelled as Gaussian distribution. Significant terms in bold.

during years of reduced inorganic nitrogen loading and concentrations (Gobler et al., 2016). Thus, in cyanobacteriadominated shallow lakes, it can be inferred that summer $\mathrm{N}$ loading might create high cyanobacterial biomass and cyanotoxin concentrations. As numerous studies have recorded that bloom-forming cyanobacteria generally are a poor food resource for both cladocerans and copepods due to their low nutritional value, e.g., insufficient amounts of essential lipids like PUFAs and sterols (Caramujo et al., 2008; MartinCreuzburg et al., 2008), poor manageability (long filaments or aggregate colonies), and toxicity (DeMott and Moxter, 1991; Kirk and Gilbert, 1992), the feedback between high cyanobacteria blooms and low zooplankton grazing driven by summer $\mathrm{N}$ loadings may produce another "vicious cycle" that expectedly boosts eutrophication (Figure 1).

To obtain a better mechanistic understanding of the effects of summer $\mathrm{N}$ loading on the resource and grazing control of phytoplankton growth in shallow eutrophic lakes, we conducted a 70-days mesocosm experiment involving contrasting $\mathrm{N}$ loadings at the shore of Lake Taihu (China), one of China's best studied lakes and known for its serious nondiazotrophic cyanobacterial (mainly Microcystis spp.) blooms (Guo et al., 2007; Qin et al., 2019). Previous bioassay experiments and field monitoring studies have revealed that the phytoplankton in Lake Taihu is generally $\mathrm{N}$ limited or $\mathrm{N}, \mathrm{P}$ co-limited during summer and fall (Xu et al., 2010; Xu et al., 2021; Paerl et al., 2011). Thus, our hypothesis was that with increasing $\mathrm{N}$ loading in summer, the phytoplankton biomass would increase due to the alleviation of $\mathrm{N}$ deficiency and higher sediment $\mathrm{P}$ release. We also expected that $\mathrm{N}$ addition would increase the biomass and dominance of grazing-resistant cyanobacteria and thereby reduce zooplankton herbivory, which, in turn, would favor phytoplankton growth via release of grazing control. 


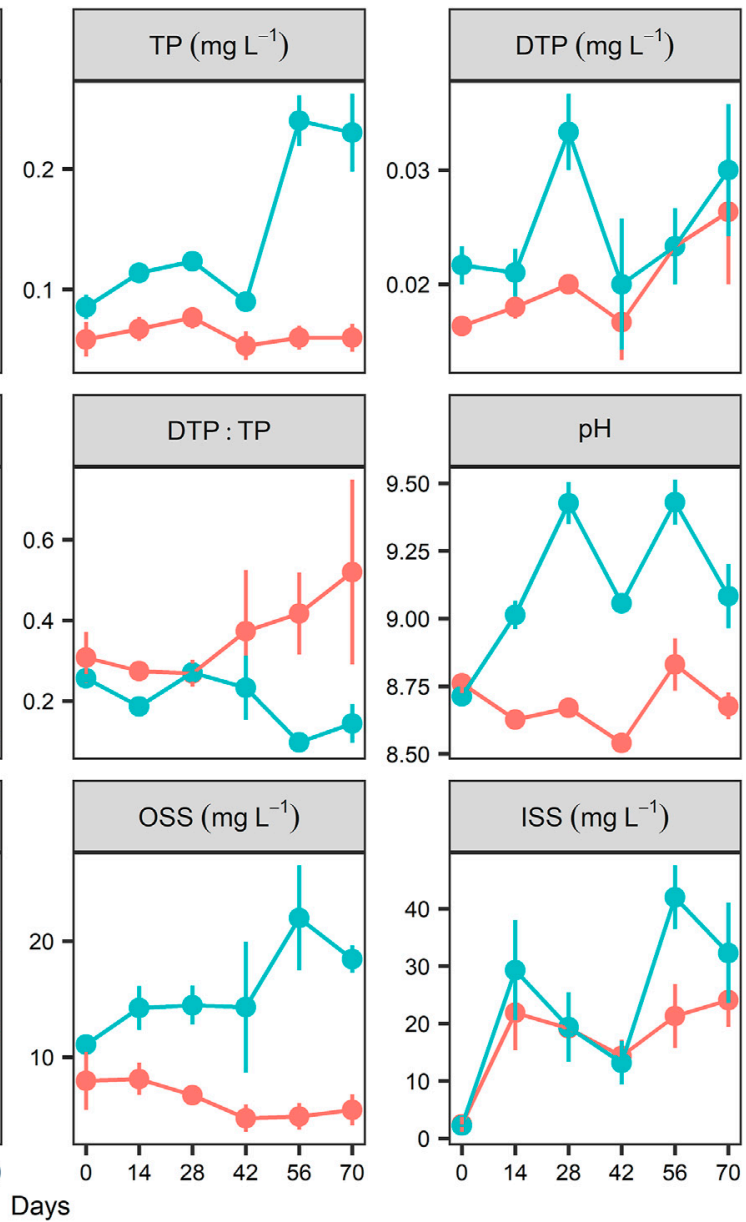

FIGURE 2 | Time series of total nitrogen (TN), total phosphorus (TP), dissolved total nitrogen (DTN), dissolved total phosphorus (DTP), TN: TP, PN: PP, DTP: TP, $\mathrm{pH}$, dissolved oxygen (DO), total suspended solids (TSS), organic suspended solids (OSS), and inorganic suspended solids (ISS) in the two nitrogen treatments. Values are mean \pm SE $(n=3)$.

\section{METHODS AND MATERIALS}

\subsection{Experimental Design}

The 70-days outdoor mesocosm experiment was conducted from June 8 to August 17, 2020, at Taihu Lake Laboratory Ecosystem Research Station (TLLER), located in Meiliang Bay on the northern edge of Lake Taihu, China. On May 30, six cylindrical, high-density polyethylene tanks $(95 \mathrm{~cm}$ height $\times$ $87 \mathrm{~cm}$ upper diameter $\times 77 \mathrm{~cm}$ bottom diameter) were filled with a $10 \mathrm{~cm}$ layer of lake sediment and $450 \mathrm{~L}$ of water collected from Meiliang Bay. The sediments had previously been sieved (mesh size: $1.7 \mathrm{~mm}$ ) to remove large invertebrates and mixed to ensure uniformity. The prepared sediment contained natural quantities of organism resting stages, which allowed zooplankton to hatch and supported community development during the experimental period. The water was also screened using a $64-\mu \mathrm{m}$ mesh filter to remove macroinvertebrates and inorganic particles before use. To simulate the prevailing omni-benthivorous fish in subtropical lakes, two juvenile crucian carp (Carassius carassius) were added to each mesocosm. Each carp had an average wet weight of $1.95 \pm$ $0.07 \mathrm{~g}$ and an average body length of $5.17 \pm 0.13 \mathrm{~cm}$. In each mesocosm, the fish approximated a natural density of $66 \mathrm{~kg} \mathrm{ha}^{-1}$, which is often recorded in Chinese subtropical or tropical lakes, for example Lake Taihu (Mao et al., 2020).

When the experiment began, nitrate $\left(\mathrm{KNO}_{3}\right)$ was supplied weekly to three mesocosms throughout the experiment. The daily $\mathrm{N}$ loading was equal to $130 \mu \mathrm{g} \mathrm{N} \mathrm{L}^{-1}$ day $^{-1}$, which was within the range of external loading in Lake Taihu (Paerl et al., 2011). The total amount of $\mathrm{N}$ added in each of the $\mathrm{N}$ treatments was equal to $4.095 \mathrm{~g}$ during the experiment. The remaining three mesocosms functioned as controls.

\subsection{Sampling and Analytical Methods 2.2.1 Water Physico-Chemical Properties and Chlorophyll a}

Samples were collected biweekly (every 14th day) during the experiment. Prior to sampling, $\mathrm{pH}$ and dissolved oxygen (DO) concentrations were measured in situ by a portable instrument (YSI 9500, YSI Inco, Yellow Springs, United States). Thereafter, a 
TABLE 2 | Best results of the generalized linear mixed model for sediment $\mathrm{P}$ fractions. Units are $\mathrm{mg} \mathrm{m}^{-2}$.

\begin{tabular}{|c|c|c|c|c|c|}
\hline & Coefficient & Estimate & SE & z-value & $P$ \\
\hline \multirow[t]{4}{*}{$\mathrm{NH}_{4} \mathrm{Cl}-\mathrm{P}$} & Intercept & 1.811 & 0.084 & 21.459 & $<0.001$ \\
\hline & $\mathrm{N}$ addition & -0.113 & 0.124 & -0.907 & 0.364 \\
\hline & Time & -0.072 & 0.104 & -0.683 & 0.494 \\
\hline & $\mathrm{N}$ addition ${ }^{*}$ Time & -0.529 & 0.196 & -2.705 & 0.007 \\
\hline \multirow[t]{3}{*}{ BD-P } & Intercept & 3.993 & 0.053 & 74.330 & $<0.001$ \\
\hline & $\mathrm{N}$ addition & 0.443 & 0.059 & 7.500 & $<0.001$ \\
\hline & Time & -0.359 & 0.057 & -6.260 & $<0.001$ \\
\hline \multirow[t]{4}{*}{$\mathrm{NaOH}-\mathrm{P}$} & Intercept & 5.887 & 0.039 & 150.270 & $<0.001$ \\
\hline & $\mathrm{N}$ addition & 0.203 & 0.051 & 4.030 & $<0.001$ \\
\hline & Time & -0.036 & 0.056 & -0.650 & 0.515 \\
\hline & $\mathrm{N}$ addition * Time & -0.327 & 0.079 & -4.110 & $<0.001$ \\
\hline \multirow[t]{4}{*}{$\mathrm{HCl}-\mathrm{P}$} & Intercept & 6.113 & 0.041 & 148.720 & $<0.001$ \\
\hline & $\mathrm{N}$ addition & 0.169 & 0.053 & 3.170 & 0.002 \\
\hline & Time & -0.148 & 0.063 & -2.370 & 0.018 \\
\hline & $\mathrm{N}$ addition ${ }^{*}$ Time & -0.298 & 0.089 & -3.330 & $<0.001$ \\
\hline Residual-P & Intercept & 4.398 & 0.137 & 32.140 & $<0.001$ \\
\hline \multirow[t]{4}{*}{ Total-P } & Intercept & 6.861 & 0.030 & 226.180 & $<0.001$ \\
\hline & $\mathrm{N}$ addition & 0.172 & 0.039 & 4.340 & $<0.001$ \\
\hline & Time & -0.093 & 0.045 & -2.070 & 0.038 \\
\hline & $\mathrm{N}$ addition ${ }^{*}$ Time & -0.256 & 0.063 & -0.450 & $<0.001$ \\
\hline
\end{tabular}

Note: All data were modelled as Gaussian distribution. Significant terms in bold.

tube sampler ( $8 \mathrm{~cm}$ diameter, $64 \mathrm{~cm}$ length) was used to collect 2-L depth-integrated water samples from each mesocosm. These water samples were subsequently taken to the laboratory for analyses of nutrient and chlorophyll $a(\mathrm{Chl}-a)$ concentrations.
Total suspended solids (TSS) was determined from 100 to $200 \mathrm{ml}$ water samples filtered through pre-combusted $\left(450^{\circ} \mathrm{C}\right.$ for $2 \mathrm{~h}$ ) and pre-weighed GF/C filters, which were then dried to a constant weight at $60^{\circ} \mathrm{C}$ for $48 \mathrm{~h}$. After determining TSS, the filters were combusted in a muffle furnace at $550^{\circ} \mathrm{C}$ for $2 \mathrm{~h}$, cooled in a desiccator, and finally weighed to determine the level of inorganic suspended solid (ISS). The organic fraction (OSS) was calculated by subtracting ISS from TSS. Total nitrogen (TN), total phosphorus (TP), total dissolved nitrogen (TDN), and total dissolved phosphorus (TDP) were determined through colorimetry after digestion with $\mathrm{K}_{2} \mathrm{~S}_{2} \mathrm{O}_{8}$ and $\mathrm{NaOH}$ solution (APHA, 1998). Particulate nitrogen (PN) or particulate phosphorus (PP) was calculated by the differences of $\mathrm{TN}$ and DTN and TP and DTP, separately. We calculated TN: TP and PN: $\mathrm{PP}$ ratios (by weight) to assess the nutrient limitation of phytoplankton (Redfield, 1958; Guildford and Hecky, 2000). We calculated DTP: TP ratios (by weight) to explain the potential mechanism of $\mathrm{P}$ release (Ma et al., 2021). Chl- $a$ concentrations were measured spectrophotometrically from matter retained on a GF/C filter and extracted in a $90 \%(\mathrm{v} / \mathrm{v})$ acetone/water solution for $24 \mathrm{~h}$. No correction was carried out for pheophytin interference (SEPA, 2002).

\subsubsection{Sediment $P$ Release}

We measured the sediment P profile on July 6 (day 28 of the experiment) and August 17 (day 70 of the experiment). After
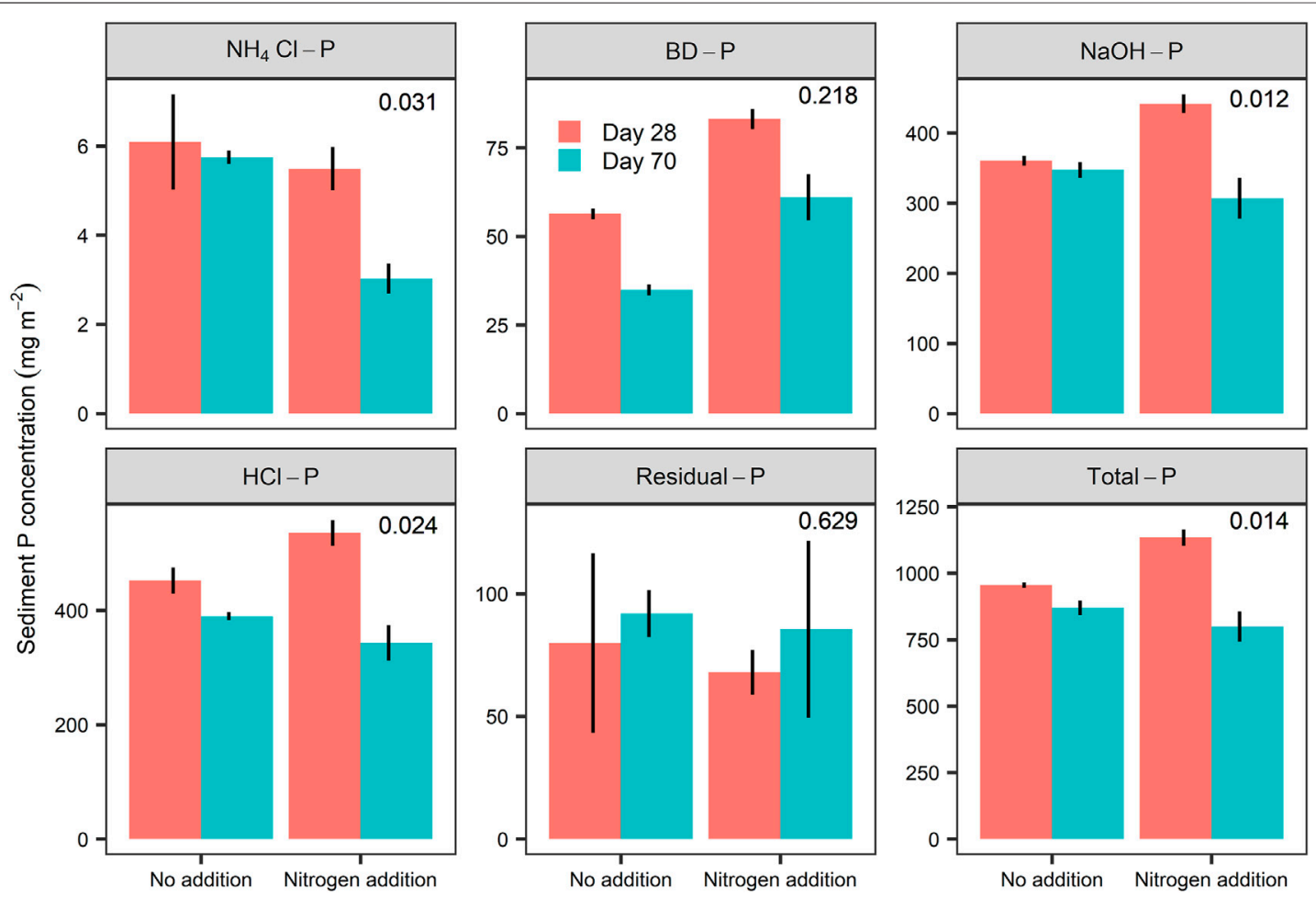

FIGURE 3 Sediment P concentrations $\left(\mathrm{mg} \mathrm{m}^{-2}\right)$ in the two nitrogen treatments calculated from the differences in $\mathrm{P}$ contents in the top $4 \mathrm{~cm}$ sediments between the two sampling events (Day 28 and Day 70$)$. Values are presented as mean $\pm \mathrm{SE}(n=3)$. Note that the range of the $Y$-axis differs among the panels. The value in each panel is the $p$ value of the interaction term (days * Nitrogen). $p<0.05$ indicated that the $P$ contents between the two sampling events were different for both nitrogen treatments. 

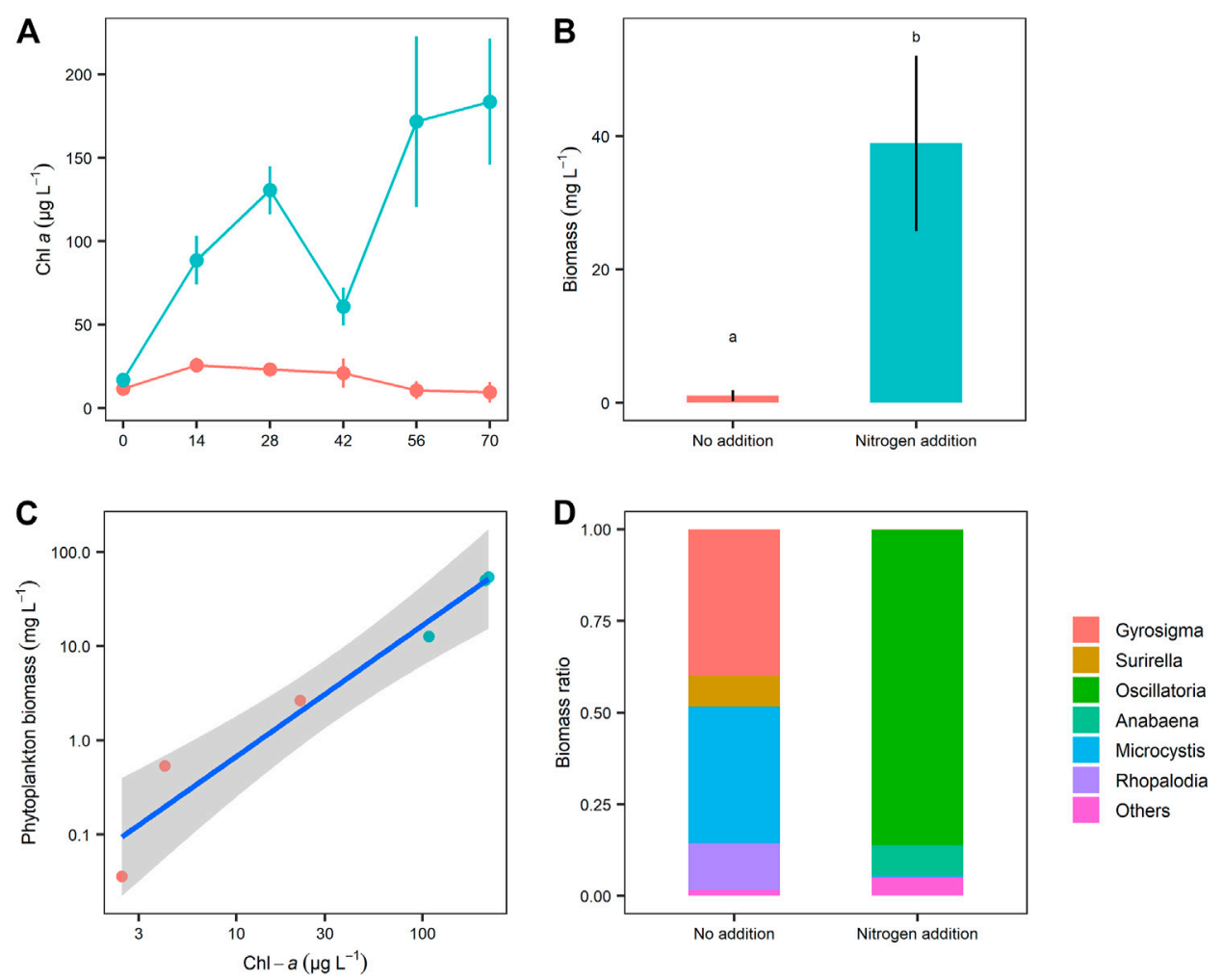

FIGURE 4 | Comparison of (A) temporal changes of chlorophyll a (Chl a) and (B) phytoplankton biomass at the end of experiment between the two nitrogen treatments, (C) the relationship between $\mathrm{Chl}$ a and phytoplankton biomass (both variables were $\log _{10}$ transformed. Linear model: $R^{2}=0.95, p<0.001$ ), and (D) phytoplankton communities at the end of experiment. Values represent mean \pm SE $(n=3)$.

water sampling, a plexiglass cylinder with an internal diameter of $3 \mathrm{~cm}$ and a length of $60 \mathrm{~cm}$ was used to extract a sediment core in the middle of each mesocosm. We sliced off the top $4 \mathrm{~cm}$ of each sediment core and measured its dry weight after drying it in the shade. Total-P of the sediment was measured according to the methods introduced by Ruban et al. (1999). P forms were also extracted according to Hupfer et al. (1995), Rydin (2000), and Meis et al. (2012). Dried sediment $(0.5 \mathrm{~g})$ was added to $50-\mathrm{ml}$ centrifuge tubes and sequentially extracted with 1) $1 \mathrm{M} \mathrm{NH}_{4} \mathrm{Cl}$ $\left(\mathrm{NH}_{4} \mathrm{Cl}-\mathrm{P}\right)$; 2) $0.11 \mathrm{M} \mathrm{NaHCO}_{3}$ and $0.11 \mathrm{M} \mathrm{Na}_{2} \mathrm{~S}_{2} \mathrm{O}_{4}$ (BD-P); 3) $0.1 \mathrm{M} \mathrm{NaOH}$ (NaOH-P); and 4) $0.5 \mathrm{M} \mathrm{HCl}$ (HCl-P); 5) the residual $\mathrm{P}$ (Residual-P) was calculated by subtracting all the extractable $\mathrm{P}$ forms from Total-P. For each mesocosm, we calculated the $\mathrm{P}$ concentration $\left(\mathrm{mg} \mathrm{m}^{-2}\right)$ using the formula:

$$
\text { P concentration }=\left(\mathrm{P}_{\mathrm{t}} * \mathrm{DW}_{\mathrm{t}}\right) / \text { Area, }
$$

where $\mathrm{P}_{\mathrm{t}}$ is the $\mathrm{P}$ content $\left(\mathrm{mg} \mathrm{kg}^{-1}\right)$ on the sampling date $t$ (Day 28 or Day 70), $\mathrm{DW}_{\mathrm{t}}$ is the dry weight of sediments on date $t$, and Area represents the sampling area of the sediments.

\subsubsection{Phytoplankton, Zooplankton, and Top-Down Control}

Besides measurements of $\mathrm{Chl} a$, phytoplankton communities were recorded at the end of the experiment (Day 70). For this purpose, a $500 \mathrm{ml}$ depth-integrated water sample from each mesocosm was treated with $5 \mathrm{ml}$ Lugol's iodine solution and sedimented for $48 \mathrm{~h}$. The supernatant was removed and the residue collected and examined at 100-400x magnification for enumeration. Phytoplankton was identified to genus level following $\mathrm{Hu}$ and Wei (2006) using, as far as possible, recent taxonomic revisions (Guiry and Guiry, 2020). The biomass of common phytoplankton taxa was calculated based on cell size measurements of at least 30 cells of each taxon using formulae for geometric shapes approximating cell forms (Zhang and Huang, 1991). For less common taxa, biomass calculations were based on fewer measurements; otherwise, at least 1,000 cells of each taxon were counted per sample.

Zooplankton were sampled on days $0,28,56$, and 70 of the experiment. A $10 \mathrm{~L}$ depth-integrated water sample was filtered through a $64 \mu \mathrm{m}$ net and the retained material was preserved in Lugol's iodine solution. The zooplankton included cladocerans, copepods, and rotifers that were counted at magnifications between $\times 40$ and $\times 100$. Species were identified according to Chiang and Du (1979) and Shen and Du (1979). Copepod nauplii were counted without further taxonomic distinction. Where possible, up to 20 individuals of each taxon were measured. Biomass (dry weight) was estimated by length-weight relationships (Bottrell 1976; McCauley et al., 1984).

To evaluate the grazing pressure of zooplankton on the phytoplankton, we calculated three top-down metrics: the ratios of zooplankton biomass to Chl- $a$ concentration, Chl- $a$ 

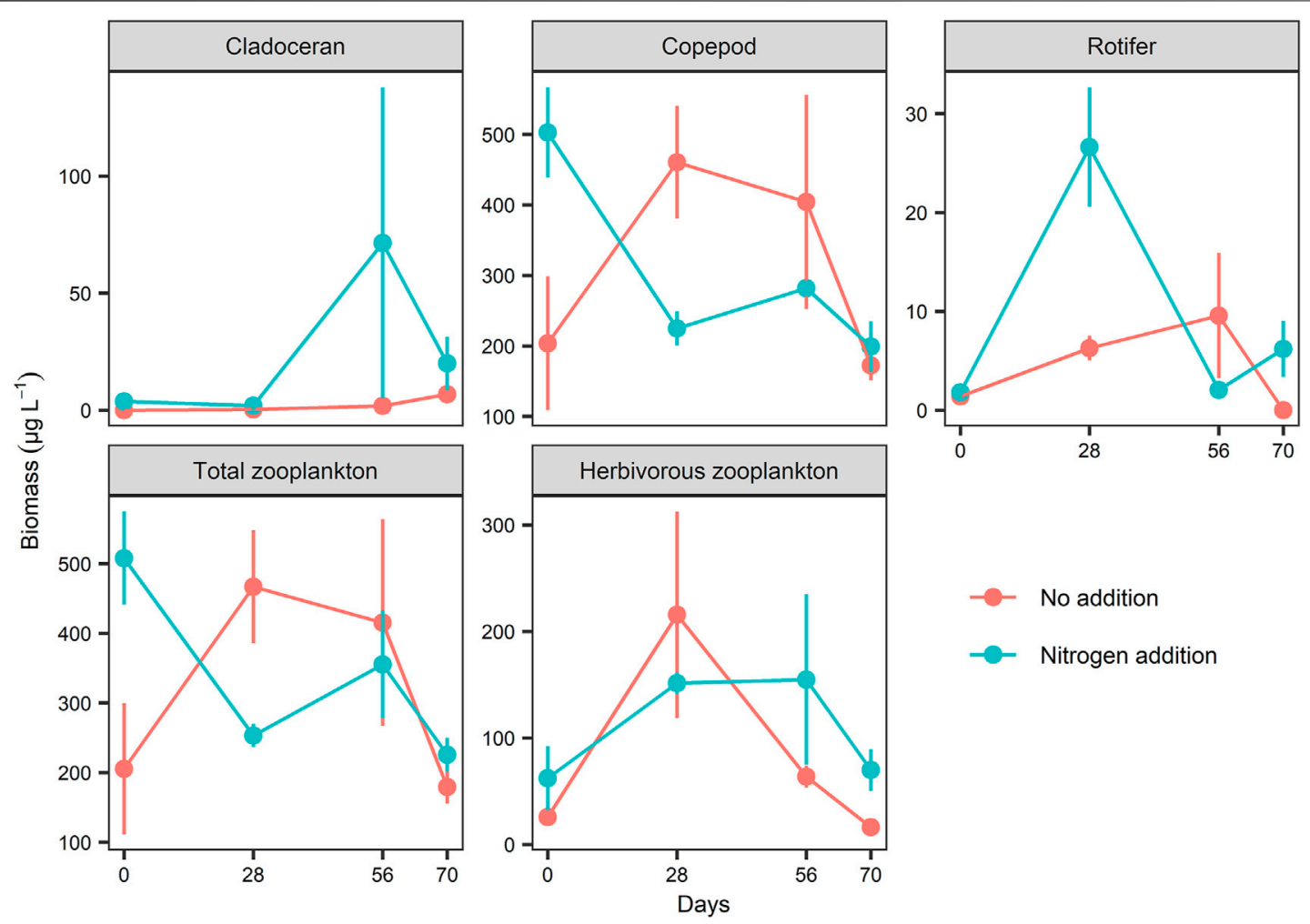

FIGURE 5 | Comparison of cladoceran, copepod, rotifer, total zooplankton and herbivorous zooplankton (without copepodites and adults of Mesocyclops leuckarti) biomass (dry weight) between the two nitrogen treatments. Values represent mean $\pm \operatorname{SE}(n=3)$.

to TP, and Chl- $a$ to TN ratios. We also calculated the densityweighted body mass of the zooplankton community and the biomass ratio of cladocerans to copepods to assess the predation strength of fish on zooplankton as large-sized individuals and taxa with low mobility (e.g., cladocerans) were more sensitive to fish predation (Jackson et al., 2007; Jeppesen et al., 2011). These metrics (when combined) are considered to be good indicators of top-down control and are widely used in long-term monitoring, cross-system lake comparison, and mesocosm studies (Gyllström et al., 2005; Jackson et al., 2007; Jeppesen et al., 2011; Liu et al., 2018; He et al., 2018, 2021).

\subsection{Data Analysis}

All data processes and statistical analyses were carried out in $R(R$ Core Team, 2020). We studied the influence of $\mathrm{N}$ addition (fixed effects) on nutrient concentrations and ratios, $\mathrm{pH}, \mathrm{DO}, \mathrm{Chl}-a$, zooplankton biomass, and top-down metrics using generalized linear mixed models with time and mesocosm identity as random effects (GLMM; Bolker et al., 2009). For each response variable, we assessed the relative fit of the two different candidate models (fixed effect: $\mathrm{N}$ addition and null) and selected the best model based on the lowest AIC value from the default anova function. We assumed Gaussian error distributions for all response variables and fitted modes using the $\operatorname{glmm} T M B$ function from the glmmTMB package (Brooks et al., 2017). We also used generalized linear mixed models to compare the differences of sediment $\mathrm{P}$ contents between both $\mathrm{N}$ scenarios at both sampling dates. To explore whether the difference of $\mathrm{P}$ contents between both $\mathrm{N}$ scenarios changed temporally, we assessed the relative fit of the five different candidate models (fixed effect: $\mathrm{N}$ addition * Time, $\mathrm{N}$ addition + Time, $\mathrm{N}$ addition, Time and null) for each $\mathrm{P}$ fraction and selected the best model based on the lowest AIC value from the default anova function. Phytoplankton biomass at the end of experiment was compared by applying Student's t test (function $t$. test) after normality (function shapiro. test) and homoscedasticity (function bartlett. test) tests.

\section{RESULTS}

\subsection{Water Physico-Chemical Properties}

Model selection by GLMMs confirmed significant positive effects of $\mathrm{N}$ addition on the TN、TDN, and TP concentrations, while its effect on the TDP concentration was not significant (Table 1; Figure 2). Model selection by GLMMs confirmed that $\mathrm{N}$ addition significantly promoted water $\mathrm{pH}, \mathrm{DO}$, and DTP: TP (Table 1; Figure 2). $\mathrm{N}$ addition did not significantly elevate $\mathrm{TN}$ : $\mathrm{TP}$ and PN: PP ratios as only the intercept term was included in the best GLMM models (Table 1; Figure 2). During the experiement, the TN: TP ratios were within the range 9-23 and PN: PP ratios were close to the therotical Redfield ratio 7 (Redfield, 1958) (Figure 2).

High turbidity was observed in both treatments, with TSS concentrations generally exceeding $20 \mathrm{mg} \mathrm{L}^{-1}$ during the 

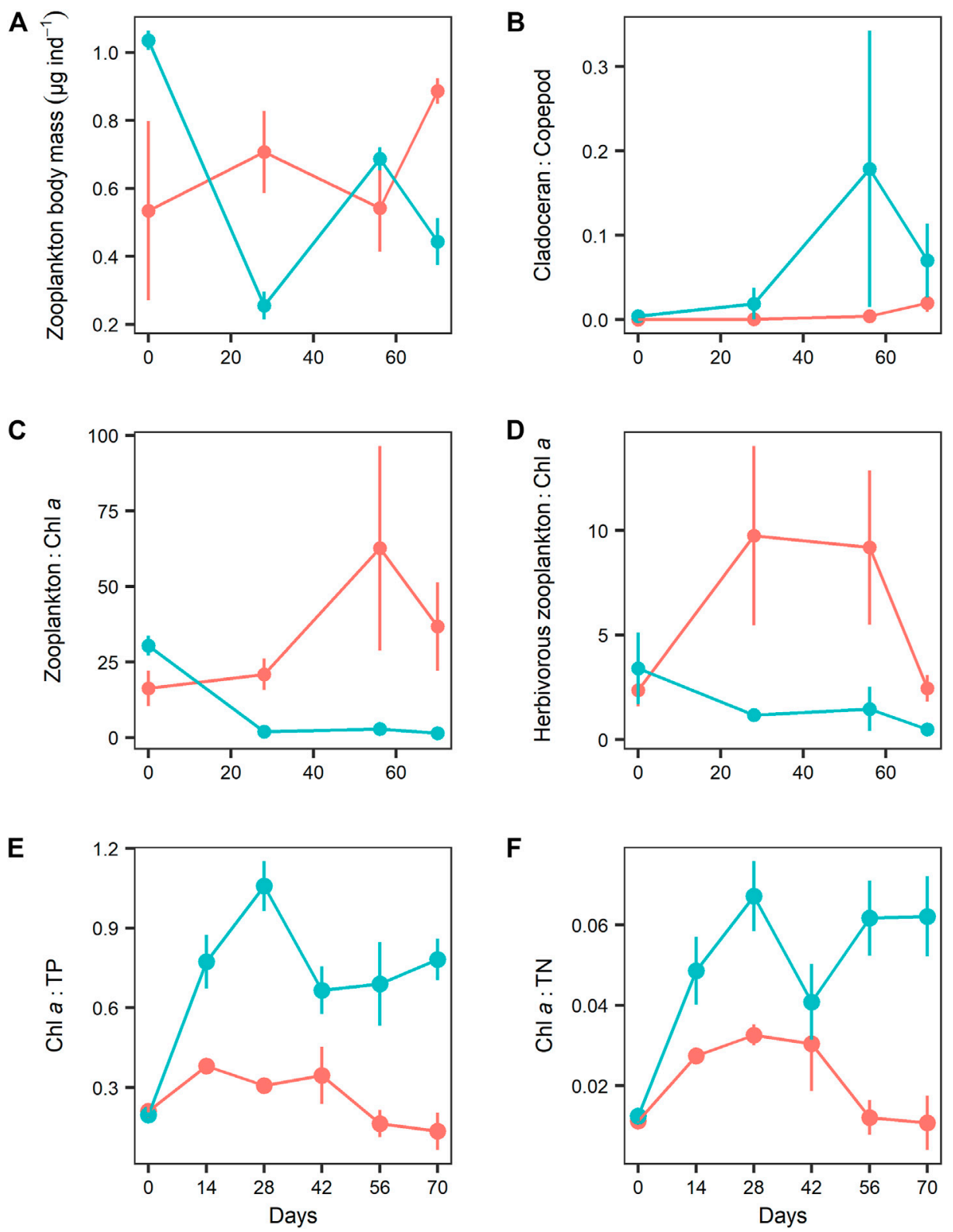

FIGURE 6 | Comparison of (A) average zooplankton body mass ( $\mu$ g dry weight per individual), (B) cladoceran to copepod biomass ratio, (C) zooplankton to chlorophyll a (Chl a) ratio, (D) herbivorous zooplankton (without copepodites and adults of Mesocyclops leuckarti) to Chl a ratio, (E) Chl a to TP ratio, and (F) Chl a to TN ratio. Between the two nitrogen treatments values represent mean $\pm \operatorname{SE}(n=3)$.

experiment. $\mathrm{N}$ addition significantly increased TSS, OSS, and ISS concentrations (Table 1; Figure 2).

\subsection{Sediment P Release}

The concentrations of Total-P and all P fractions except Residual$\mathrm{P}$ at the end of the experiment (Day 70) were significantly lower than on Day 28 (Table 2; Figure 3). Moreover, the significant impact of the interactions of $\mathrm{N}$ addition and time on Total-P, $\mathrm{NH}_{4} \mathrm{Cl}-\mathrm{P}, \mathrm{NaOH}-\mathrm{P}$, and $\mathrm{HCl}-\mathrm{P}$ means that the magnitude of temporal declines was significantly greater in the $\mathrm{N}$ addition than in the control treatments (Table 2; Figure 3). $\mathrm{N}$ addition also significantly reduced BD-P, but its interaction with time was not significant (Table 2; Figure 3). No significance of $\mathrm{N}$ addition, time, and their interactions for Residual-P was observed in our study (Table 2; Figure 3).

\subsection{Phytoplankton}

$\mathrm{N}$ addition significantly boosted phytoplankton growth as both the Chl-a concentration (Table 1) and phytoplankton biomass (biovolume) ( $t$-test, $p=0.008$ ) were much higher in the $\mathrm{N}$ mesocosms than in the controls (Figures $4 \mathbf{A}, \mathbf{B}$ ). Meanwhile, we found a significant positive linear relation 
between phytoplankton Chl- $a$ and biomass at the end of the experiment, which indicated that chlorophyll $a$ could be used as an estimate of phytoplankton biomass in our study (Figure 4C). At the end of the experiment, large differences in phytoplankton communities between the two treatments were observed (Figure 4D). In the control mesocosms, the phytoplankton was dominated by diatoms (mainly Gyrosigma and Surirella), while filamentous cyanobacteria, e.g., Oscillatoria and Anabaena, dominated in the $\mathrm{N}$ treatment (Figure 4D). The differences in cyanobacteria and diatom dominance (\%) between the two treatments were significant ( $t$-test, $p=0.027$ for cyanobacteria; $p=0.029$ for diatoms; Figure 4D).

\subsection{Zooplankton and Grazing Control}

A total of 21 zooplankton taxa were recorded in the two treatments across the entire experimental period, including six cladoceran species (Ceriodaphnia quadrangular, Chydorus sphaericus, Moina sp., Bosmina sp. Alona sp., and Diaphanosoma sp.), two copepods (Mesocyclops leuckarti and Sinocalanus dorrii), and 13 rotifers (mainly Conochilus unicornis and Brachionus spp.). In our study, Mesocyclops leuckarti was the dominant species in both treatments. As the adult and most copepodid stages of this species can be carnivorous, we separately calculated total (all species included) and herbivorous zooplankton (with elimination of copepodites and adults of $M$. leuckarti) biomass in our study. Model selection by GLMMs revealed that no significant effect of $\mathrm{N}$ addition on cladoceran, copepod, and total and herbivorous zooplankton biomass occurred, but rotifer biomass was significantly higher in the $\mathrm{N}$ treatments than in the controls (Table 1; Figure 5).

No significant effects of $\mathrm{N}$ addition on zooplankton body mass and cladoceran to copepod biomass ratios were observed (Table 1; Figures 6A,B). However, $\mathrm{N}$ addition significantly reduced both total zooplankton and herbivorous zooplankton biomass to Chl- $a$ ratios and increased the chlorophyll $a$ to TP and TN ratios (Table 1; Figures 6C-F).

\section{DISCUSSION}

Understanding the ecological mechanisms that underlie eutrophication in response to nutrient loading has long been an urgent objective in limnological research (Smith and Schindler, 2009). We found that summer $\mathrm{N}$ addition increased not only the $\mathrm{N}$ levels but also $\mathrm{P}$ availability for phytoplankton growth. We also found that $\mathrm{N}$ addition lowered the zooplankton-phytoplankton biomass ratio and promoted the phytoplankton yield, expressed as the chlorophyll a to $\mathrm{TP}$ and $\mathrm{TN}$ ratios, indicating that $\mathrm{N}$ addition favored phytoplankton growth through reduction of zooplankton grazing. Accordingly, our study suggests that in eutrophic shallow lakes, $\mathrm{N}$ loading may increase the phytoplankton biomass in summer via both resource and grazer effects. Our study thus showed that decreasing $\mathrm{N}$ loading may lead to reduced eutrophication in summer in shallow lakes, which is consistent with long-term field investigations conducted in temperate shallow waterbodies, e.g., Lake Müggelsee in Germany and shallow meres in England (Moss et al., 2005; Shatwell and Köhler, 2019).

As there was no external P loading in our study, the enhanced water TP concentrations induced by $\mathrm{N}$ loading can only be attributed to sediment $\mathrm{P}$ release, which was partially supported by the greater temporal reductions of sediment Total-P in the $\mathrm{N}$ addition treatments than in the control (Figure 3). Promotion by $\mathrm{N}$ addition of TP concentrations has been widely observed in eutrophic shallow waterbodies where sediments serve as an important P source (Jensen and Andersen, 1992; Xie et al., 2003; Sagrario et al., 2005; He et al., 2015; Ma et al., 2018). The mechanisms behind include increases in diffusion, bacteria activity, and $\mathrm{pH}$ and in the degradation of settled algae via the feedback between an $\mathrm{N}$-induced high algal biomass and sediment P (Gao et al., 2014; Ma et al., 2018; 2021). Some of these mechanisms were also observed in our study. For instance, we found a clear decline in the contribution of TDP to TP after Day 42 and promotion of $\mathrm{pH}$ by $\mathrm{N}$ addition (Figure 2), indicating a high potential of diffusion (Xie et al., 2003; Chen et al., 2018; $\mathrm{Ma}$ et al., 2021) and desorption of $\mathrm{PO}_{4}{ }^{3-}$ from suspended surface sediments (Koski-Vähälä and Hartikainen 2001; Søndergaard et al., 2003; Jin et al., 2006; Gao et al., 2014). This was also evidenced by the high reduction of $\mathrm{NH}_{4} \mathrm{Cl}-\mathrm{P}$ and $\mathrm{NaOH}-\mathrm{P}$ caused by $\mathrm{N}$ addition in our study (Figure 2; Figure 3). Moreover, in our study, sediment $\mathrm{P}$ release may also have been enhanced by increased strength of sediment resuspension (Søndergaard et al., 2003; He et al., 2015) as the ISS concentrations in the $\mathrm{N}$ addition treatments were higher than in the control mesocosms (Figure 2). A possible explanation of the stronger resuspension by $\mathrm{N}$ loading, through speculative, is that fish had grown bigger in the $\mathrm{N}$ addition mesocosms due to the higher food production, as seen in the study by Wang et al. (2017). However, it is important to note that the reductions of Total-P in top $4 \mathrm{~cm}$ sediment were much larger than the increases of TP in the water. This means that only a small fraction of $\mathrm{P}$ in the sediment surface was released into the overlying water and most of the $\mathrm{P}$ was transported to the deeper sediment layers, likely due to the increased DO (Figure 2) and potential oxidized thickness by high $\mathrm{NO}_{3}{ }^{-}$addition (Jensen and Andersen, 1992). Overall, due to the simultaneous increase of water TP concentrations, persistent $\mathrm{N}$ addition did not significantly increase either the TN: TP or the PN: PP ratios, with phytoplankton growth likely being co-limited by $\mathrm{N}$ and $\mathrm{P}$ during the experimental period (Figure 2). The external $\mathrm{N}$ loading caused high internal $\mathrm{P}$ loading, thereby snowballing the eutrophication process via increased resources, as shown in Figure 1.

In our study, $\mathrm{N}$ addition caused a dominance replacement of diatoms by cyanobacteria (Figure 4D), as also seen in similar previous mesocosm experiments and lake investigations (Beaulieu et al., 2013; He et al., 2015; Gobler et al., 2016). The increased cyanobacteria dominance caused by $\mathrm{N}$ loading may be attributed to the increased competitive advantage by the shadingresistant cyanobacteria (e.g., Oscillatoria) in turbid and nutrientenriched environments (Havens et al., 2003). Interestingly, $\mathrm{N}$ 
addition increased, not reduced, the dominance of Anabaena, an $\mathrm{N}_{2}$-fixing taxon, in our study. This contrasted with the common view that declining $\mathrm{N}$ inputs would favor $\mathrm{N}_{2}$-fixing cyanobacteria in lakes (Schindler et al., 2008), but concurred with observation from studies of a large number of Danish shallow lakes (Jensen et al., 1994; Jeppesen et al., 2005), suggesting that the mechanisms underlying the occurrence of $\mathrm{N}_{2}$-fixing cyanobacteria in lakes are complex (Kolzau et al., 2018; Shatwell and Köhler, 2019). In our study, both TN: TP and PN: PP ratios were not obviously changed by $\mathrm{N}$ addition (Figure 2), which indicates that the growth of Anabaena in $\mathrm{N}$ addition mesocosms was unlikely caused by $\mathrm{N}$ deficiency.

Nutrient availability, however, was not the only reason why $\mathrm{N}$ addition increased the summer phytoplankton growth as it could not explain the observed elevation of the Chl- $a$ : TP and Chl- $a$ : TN ratios following $\mathrm{N}$ addition. The increased amount of chlorophyll $a$ per unit of $\mathrm{N}$ and $\mathrm{P}$ suggests that factors other than resources affected the accumulation of phytoplankton biomass. Combined with the low total and herbivorous zooplankton to phytoplankton biomass ratios in the treatments with $\mathrm{N}$ addition, the results indicate that phytoplankton was also favored by the reduced herbivory. Similarly, Bergström et al. (2021) found much lower zooplankton to phytoplankton biomass ratios after wholelake fertilization with $\mathrm{N}$ along a gradient of lake DOC concentrations. It could be argued that the increased Chl- $a$ to $\mathrm{TP}$ and $\mathrm{TN}$ ratios by $\mathrm{N}$ addition were not due to changes in zooplankton herbivory, but instead were a result of changes of cellular pigment contents between phytoplankton groups (Nicholls and Dillon, 1978). However, this is not the case as we found a close relationship between phytoplankton biomass and Chl $a$ concentration (Figure 4C).

In our study, the decline of zooplankton grazing by $\mathrm{N}$ addition could not be attributed to increased fish predation as both indicators, average zooplankton body mass and cladoceran to copepod biomass ratio, showed no obvious changes (Figure 6). Thus, changes in phytoplankton properties driven by $\mathrm{N}$ addition are the most likely explanation of the decreased zooplankton grazing. Supporting this view, an obvious $\mathrm{N}$-driven substitution of diatoms by filamentous cyanobacteria was observed (Figure 4D). The latter are generally considered as lowquality food for both copepods and cladocerans (Caramujo et al., 2008; Martin-Creuzburg et al., 2008). For instance, laboratory feeding experiments revealed that when the freshwater harpacticoid copepod Attheyella trispinosa grew on cyanobacteria (Leptolyngbya foveolarum and Cylindrospermum stagnale), its survival was reduced, and the development from the first copepodite stage to adult lasted $26 \%$ longer than when they grew on diatoms (Achnanthes lanceolate and Nitzschia perminuta) (Caramujo et al., 2008). Moreover, cyanobacteria, e.g., Oscillatoria and Anabaena, may also resist zooplankton grazing because of poor manageability due to their long filaments and potential toxicity (DeMott and Moxter, 1991; Koski et al., 1999; Engström-Öst et al., 2015). Although feeding experiments have confirmed that Mesocyclops and other copepods may feed size-selectively on filaments and discriminate against toxic strains (DeMott and Moxter, 1991: Kumar and Ramakrishna Rao, 1999; Sarma et al., 2013), it is energetically costly and compensated for by a reduction in population size (DeMott and Moxter, 1991; Koski et al., 1999; Engström-öst et al., 2015).

In recent decades, increasing $\mathrm{TN}$ : TP ratios resulting from an imbalance between $\mathrm{N}$ and $\mathrm{P}$ supplies have been observed in many freshwater shallow lakes (Tong et al., 2020). However, the necessity of controlling $\mathrm{N}$ inputs remains a subject of debate (Schindler et al., 2008; Conley et al., 2009; Paerl et al., 2011; Shatwell and Köhler, 2019). Our results from a shallow eutrophic mesocosm study clearly showed that $\mathrm{N}$ inputs disproportionally increased the summer phytoplankton biomass (both Chl $a$ and Chl $a$ to TP or TN ratios) due to the combined effects of resource and grazing control. Our study therefore implies that $\mathrm{N}$ loading may not only physiologically support phytoplankton growth, it also modifies the abiotic and biotic environment and thereby creates conditions that are beneficial for phytoplankton growth. Thus, alleviation of eutrophication in shallow eutrophic lakes requires a balanced and strategic approach to appropriately control both nutrients ( $\mathrm{N}$ and $\mathrm{P}$ ).

\section{DATA AVAILABILITY STATEMENT}

The original contributions presented in the study are included in the article/Supplementary Material, further inquiries can be directed to the corresponding author/s.

\section{ETHICS STATEMENT}

The animal study was reviewed and approved by All experimental procedures involving fish were approved by the Institutional Animal Care and Use Committee of the Nanjing Institute of Geography and Limnology, Chinese Academy of Sciences.

\section{AUTHOR CONTRIBUTIONS}

$\mathrm{HH}$ : Conceptualization, methodology, investigation, data curation, writing-original draft. KC: Investigation, data curation, formal analysis, writing-review and editing. YD: Conceptualization, data curation, writing-review and editing. KL: Conceptualization, methodology, writing-review and editing, funding acquisition. ZL: Conceptualization, methodology, writing - review and editing, funding acquisition. EJ: Conceptualization, methodology, writing-review and editing. MS: Conceptualization, writing-review and editing. All authors contributed to the interpretation of the analysis and its implications and to the revision of intellectually important content, and all the authors approved of the manuscript's final publication and agree to be accountable for the work. 


\section{FUNDING}

This study was financially supported by National Science Foundation of China (Nos. 31930074; 31971473) and Chinese National Key Research and Development Project (No. 2017YFA0605201). EJ was supported by AQUACOSM (Network of Leading European AQUAtic MesoCOSM Facilities Connecting Mountains to Oceans from the Arctic to the Mediterranean), AnaEE Denmark (anaee.dk), and the Tübitak program BIDEB 2232 (project 118C250). All experimental procedures involving fish were approved by the

\section{REFERENCES}

Andersen, J. M. (1982). Effect of Nitrate Concentration in Lake Water on Phosphate Release from the Sediment. Water Res. 16, 1119-1126. doi:10.1016/0043-1354(82)90128-2

APHA (1998). Standard Methods for the Examination of Water and Waste Water. 20th ed. Washington, DC: American Public Health Association.

Beaulieu, M., Pick, F., and Gregory-Eaves, I. (2013). Nutrients and Water Temperature Are Significant Predictors of Cyanobacterial Biomass in a 1147 Lakes Data Set. Lim 58, 1736-1746. doi:10.4319/lo.2013.58.5.1736

Bergström, A.-K., Deininger, A., Jonsson, A., Karlsson, J., and Vrede, T. (2021). Effects of Nitrogen Enrichment on Zooplankton Biomass and N:P Recycling Ratios across a DOC Gradient in Northern-Latitude Lakes. Hydrobiologia 848, 4991-5010. doi:10.1007/s10750-021-04689-5

Bolker, B. M., Brooks, M. E., Clark, C. J., Geange, S. W., Poulsen, J. R., Stevens, M. H. H., et al. (2009). Generalized Linear Mixed Models: A Practical Guide for Ecology and Evolution. Trends Ecol. Evol. 24, 127-135. doi:10.1016/ j.tree.2008.10.008

Boström, B., and Pettersson, K. (1982). Different Patterns of Phosphorus Release from lake Sediments in Laboratory Experiments. Hydrobiologia 91-92, 415-429. doi:10.1007/PL00020032

Bottrell, H. C. (1976). A Review of Some Problems in Zooplankton Production Studies. Norw. J. Zool. 24, 419-456.

Brooks, M. E., Kristensen, K., Benthem, K. J. v., Magnusson, A., Berg, C. W., Nielsen, A., et al. (2017). glmmTMB Balances Speed and Flexibility Among Packages for Zero-Inflated Generalized Linear Mixed Modeling. R. Journal 9, 378-400. doi:10.32614/rj-2017-066

Caramujo, M. J., Boschker, H. T., and Admiraal, W. I. M. (2008). Fatty Acid Profiles of Algae Mark the Development and Composition of Harpacticoid Copepods. Freshw. Biol 53, 77-90. doi:10.1111/j.13652427.2007.01868.x

Chen, M., Ding, S., Chen, X., Sun, Q., Fan, X., Lin, J., et al. (2018). Mechanisms Driving Phosphorus Release during Algal Blooms Based on Hourly Changes in Iron and Phosphorus Concentrations in Sediments. Water Res. 133, 153-164. doi:10.1016/j.watres.2018.01.040

Chiang, S. C., and Du, N. S. (1979). Fauna Sinica; Crustacea: Freshwater Cladocera. Beijing: Science press.

Conley, D. J., Paerl, H. W., Howarth, R. W., Boesch, D. F., Seitzinger, S. P., Havens, K. E., et al. (2009). Controlling Eutrophication: Nitrogen and Phosphorus. Science 323, 1014-1015. doi:10.1126/science.1167755

DeMott, W. R., and Moxter, F. (1991). Foraging Cyanobacteria by Copepods: Responses to Chemical Defense and Resource Abundance. Ecology 72, 1820-1834. doi:10.2307/1940981

Elser, J. J., Bracken, M. E. S., Cleland, E. E., Gruner, D. S., Harpole, W. S., Hillebrand, H., et al. (2007). Global Analysis of Nitrogen and Phosphorus Limitation of Primary Producers in Freshwater, Marine and Terrestrial Ecosystems. Ecol. Lett. 10 (12), 1135-1142. doi:10.1111/j.14610248.2007.01113.x

Engström-Öst, J., Brutemark, A., Vehmaa, A., Motwani, N. H., and Katajisto, T. (2015). Consequences of a Cyanobacteria Bloom for Copepod Reproduction, Mortality and Sex Ratio. J. Plankton Res. 37, 388-398. doi:10.1093/plankt/ fbv004
Institutional Animal Care and Use Committee of the Nanjing Institute of Geography and Limnology, Chinese Academy of Sciences.

\section{ACKNOWLEDGMENTS}

We would like to thank the Taihu Laboratory for Lake Ecosystem Research (TLLER) for providing us with the experimental facility for this study. We also express our gratitude to Anne Mette Poulsen for linguistic assistance.

Gao, Y., Cornwell, J. C., Stoecker, D. K., and Owens, M. S. (2014). Influence of Cyanobacteria Blooms on Sediment Biogeochemistry and Nutrient Fluxes. Limnol. Oceanogr. 59, 959-971. doi:10.4319/lo.2014.59.3.0959

Gobler, C. J., Burkholder, J. M., Davis, T. W., Harke, M. J., Johengen, T., Stow, C. A., et al. (2016). The Dual Role of Nitrogen Supply in Controlling the Growth and Toxicity of Cyanobacterial Blooms. Harmful Algae 54, 87-97. doi:10.1016/ j.hal.2016.01.010

Gonzalez Sagrario, M. A., Jeppesen, E., Gomà, J., Sondergaard, M., Jensen, J. P., Lauridsen, T., et al. (2005). Does High Nitrogen Loading Prevent Clear-Water Conditions in Shallow Lakes at Moderately High Phosphorus Concentrations? Freshw. Biol 50 (1), 27-41. doi:10.1111/j.13652427.2004.01290.x

Guildford, S. J., and Hecky, R. E. (2000). Total Nitrogen, Total Phosphorus, and Nutrient Limitation in Lakes and Oceans: Is There a Common Relationship? Limnol. Oceanogr. 45, 1213-1223. doi:10.4319/ lo.2000.45.6.1213

Guiry, M. D., and Guiry, G. M. (2020). Algaebase. Galway: World- wide Electronic PublicationNational University of Ireland. Available at: http://www.algaebase. org (Accessed November 07, 2020).

Guo, L. (2007). Doing battle with the green monster of Taihu Lake. Science. 317, 1166. doi:10.1126/science.317.5842.1166

Gyllström, M., Hansson, L.-A., Jeppesen, E., Criado, F. G., Gross, E., Irvine, K., et al. (2005). The Role of Climate in Shaping Zooplankton Communities of Shallow Lakes. Limnol. Oceanogr. 50, 2008-2021. doi:10.4319/ lo.2005.50.6.2008

Havens, K. E., James, R. T., East, T. L., and Smith, V. H. (2003). N:P Ratios, Light Limitation, and Cyanobacterial Dominance in a Subtropical Lake Impacted by Non-Point Source Nutrient Pollution. Environ. Pollut. 122, 379-390. doi:10.1016/s0269-7491(02)00304-4

He, H., Jin, H., Jeppesen, E., Li, K., Liu, Z., and Zhang, Y. (2018). Fish-Mediated Plankton Responses to Increased Temperature in Subtropical Aquatic Mesocosm Ecosystems: Implications for lake Management. Water Res. 144, 304-311. doi:10.1016/j.watres.2018.07.055

He, H., Kang, Y., and Liu, Z. (2015). Nitrogen Inputs Enhance Phytoplankton Growth during Sediment Resuspension Events: A Mesocosm Study. Hydrobiologia 744, 297-305. doi:10.1007/s10750-014-2085-0

He, H., Ning, X., Chen, K., Li, Q., Li, K., Liu, Z., et al. (2021). Intraguild Predation Dampens Trophic Cascades in Shallow Aquatic Mesocosms in the Subtropics: Implications for Lake Restoration by Biomanipulation. Freshw. Biol. 66, 1571-1580. doi:10.1111/fwb.13739

Hu, H. J., and Wei, Y. X. (2006). The Freshwater Algae of China: Systematics, Taxonomy and Ecology. Beijing: Science Press. (in Chinese).

Hupfer, M., Gächter, R., and Giovanoli, R. (1995). Transformation of Phosphorus Species in Settling Seston and during Early Sediment Diagenesis. Aquat. Sci. 57, 305-324. doi:10.1007/BF00878395

Jackson, L. J., Lauridsen, T. L., Søndergaard, M., and Jeppesen, E. (2007). A Comparison of Shallow Danish and Canadian Lakes and Implications of Climate Change. Freshw. Biol 52, 1782-1792. doi:10.1111/j.13652427.2007.01809.x

Jensen, H. S., and Andersen, F. O. (1992). Importance of Temperature, Nitrate, and $\mathrm{pH}$ for Phosphate Release from Aerobic Sediments of Four Shallow, Eutrophic Lakes. Limnol. Oceanogr. 37, 577-589. doi:10.4319/ lo.1992.37.3.0577 
Jensen, J. P., Jeppesen, E., Olrik, K., and Kristensen, P. (1994). Impact of Nutrients and Physical Factors on the Shift from Cyanobacterial to Chlorophyte Dominance in Shallow Danish Lakes. Can. J. Fish. Aquat. Sci. 51, 1692-1699. doi:10.1139/f94-170

Jeppesen, E., Jensen, J. P., Sondergaard, M., and Lauridsen, T. L. (2005). Response of Fish and Plankton to Nutrient Loading Reduction in Eight Shallow Danish Lakes with Special Emphasis on Seasonal Dynamics. Freshw. Biol 50, 1616-1627. doi:10.1111/j.1365-2427.2005.01413.x

Jeppesen, E., Nõges, P., Davidson, T. A., Haberman, J., Nõges, T., Blank, K., et al. (2011). Zooplankton as Indicators in Lakes: a Scientific-Based Plea for Including Zooplankton in the Ecological Quality Assessment of Lakes According to the European Water Framework Directive (WFD). Hydrobiologia 676, 279-297. doi:10.1007/s10750-011-0831-0

Jin, X., Wang, S., Pang, Y., and Chang Wu, F. (2006). Phosphorus Fractions and the Effect of $\mathrm{pH}$ on the Phosphorus Release of the Sediments from Different Trophic Areas in Taihu Lake, China. Environ. Pollut. 139, 288-295. doi:10.1016/j.envpol.2005.05.010

Kirk, K. L., and Gilbert, J. J. (1992). Variation in Herbivore Response to Chemical Defenses: Zooplankton Foraging on Toxic Cyanobacteria. Ecology 73, 2208-2217. doi:10.2307/1941468

Kolzau, S., Dolman, A. M., Voss, M., and Wiedner, C. (2018). The Response of Nitrogen Fixing Cyanobacteria to a Reduction in Nitrogen Loading. Internat Rev. Hydrobiol 103, 5-14. doi:10.1002/iroh.201601882

Koski, M., Engström, J., and Viitasalo, M. (1999). Reproduction and Survival of the Calanoid Copepod Eurytemora Affinis Fed with Toxic and Non-Toxic Cyanobacteria. Mar. Ecol. Prog. Ser. 186, 187-197. doi:10.3354/meps186187

Koski-Vähälä, J., and Hartikainen, H. (2001). Assessment of the Risk of Phosphorus Loading due to Resuspended Sediment. J. Environ. Qual. 30, 960-966. doi:10.2134/jeq2001.303960x

Kumar, R. A. M., and Ramakrishna Rao, T. (1999). Demographic Responses of Adult Mesocyclops Thermocyclopoides (Copepoda, Cyclopoida) to Different Plant and Animal Diets. Freshw. Biol 42 (3), 487-501. doi:10.1046/j.13652427.1999.00485.x

Liu, Z., Hu, J., Zhong, P., Zhang, X., Ning, J., Larsen, S. E., et al. (2018). Successful Restoration of a Tropical Shallow Eutrophic Lake: strong Bottom-Up but Weak Top-Down Effects Recorded. Water Res. 146, 88-97. doi:10.1016/ j.watres.2018.09.007

Lorenz, P., Trommer, G., and Stibor, H. (2019). Impacts of Increasing Nitrogen: Phosphorus Ratios on Zooplankton Community Composition and whitefish ( Coregonus Macrophthalmus ) Growth in a Pre-Alpine Lake. Freshw. Biol. 64, 1210-1225. doi:10.1111/fwb.13296

Ma, S.-N., Wang, H.-J., Wang, H.-Z., Zhang, M., Li, Y., Bian, S.-J., et al. (2021). Effects of Nitrate on Phosphorus Release from Lake Sediments. Water Res. 194, 116894. doi:10.1016/j.watres.2021.116894

Ma, S. N., Wang, H. J., Wang, H. Z., Li, Y., Liu, M., Liang, X. M., et al. (2018). High Ammonium Loading Can Increase Alkaline Phosphatase Activity and Promote Sediment Phosphorus Release: A Two-Month Mesocosm experiment. Water Res. 145, 388-397. doi:10.1016/j.watres.2018.08.043

Mao, Z., Gu, X., Cao, Y., Zhang, M., Zeng, Q., Chen, H., et al. (2020). The Role of Top-Down and Bottom-Up Control for Phytoplankton in a Subtropical Shallow Eutrophic Lake: Evidence Based on Long-Term Monitoring and Modeling. Ecosystems 23, 1449-1463. doi:10.1007/s10021-020-00480-0

Martin-Creuzburg, D., von Elert, E., and Hoffmann, K. H. (2008). Nutritional Constraints at the Cyanobacteria-Daphnia Magna Interface: The Role of Sterols. Limnol. Oceanogr. 53, 456-468. doi:10.4319/lo.2008.53.2.0456

McCauley, E. (1984) "The Estimation of the Abundance and Biomass of Zooplankton in Samples," in A Manual on Methods for the Assessment of Secondary Productivity in Fresh Waters. Editors J. Downing and F. H. Rigler (Oxford: Blackwell Scientific), 228-265.

Meis, S., Spears, B. M., Maberly, S. C., O'Malley, M. B., and Perkins, R. G. (2012). Sediment Amendment with Phoslock in Clatto Reservoir (Dundee, UK): Investigating Changes in Sediment Elemental Composition and Phosphorus Fractionation. J. Environ. Manage. 93, 185-193. doi:10.1016/ j.jenvman.2011.09.015

Moss, B., Barker, T., Stephen, D., Williams, A. E., Balayla, D. J., Beklioglu, M., et al. (2005). Consequences of Reduced Nutrient Loading on a Lake System in a Lowland Catchment: Deviations from the Norm? Freshw. Biol 50, 1687-1705. doi:10.1111/j.1365-2427.2005.01416.x
Nicholls, K. H., and Dillon, P. J. (1978). An Evaluation of PhosphorusChlorophyll-Phytoplankton Relationships for Lakes. Int. Revue Ges. Hydrobiol. Hydrogr. 63 (2), 141-154. doi:10.1002/iroh.19780630203

Paerl, H. W., Xu, H., McCarthy, M. J., Zhu, G., Qin, B., Li, Y., et al. (2011). Controlling Harmful Cyanobacterial Blooms in a Hyper-Eutrophic lake (Lake Taihu, China): The Need for a Dual Nutrient (N \& P) Management Strategy. Water Res. 45, 1973-1983. doi:10.1016/j.watres.2010.09.018

Peñuelas, J., Poulter, B., Sardans, J., Ciais, P., Van Der Velde, M., Bopp, L., et al. (2013). Human-Induced Nitrogen-Phosphorus Imbalances Alter Natural and Managed Ecosystems across the globe. Nat. Commun. 4, 1-10. doi:10.1038/ ncomms 3934

Peñuelas, J., Sardans, J., Rivas-ubach, A., and Janssens, I. A. (2012). The HumanInduced Imbalance between C, N and P in Earth's Life System. Glob. Change Biol. 18, 3-6. doi:10.1111/j.1365-2486.2011.02568.x

Qin, B., Paerl, H. W., Brookes, J. D., Liu, J., Jeppesen, E., Zhu, G., et al. (2019). Why Lake Taihu Continues to be Plagued with Cyanobacterial Blooms Through 10 years (2007-2017) Efforts. Sci. Bull. 64, 354-356. doi:10.1016/ j.scib.2019.02.008

R Core Team(2020). R: A Language and Environment for Statistical Computing. Vienna: R Foundation for Statistical Computing. Available at: https://www.Rproject.org/ (Accessed September 25, 2020).

Redfield, A. C. (1958). The Biological Control of Chemical Factors in the Environment. Am. Sci. 46, 230A-221A.

Ruban, V., López-Sánchez, J. F., Pardo, P., Rauret, G., Muntau, H., and Quevauviller, P. (1999). Selection and Evaluation of Sequential Extraction Procedures for the Determination of Phosphorus Forms in Lake Sediment. J. Environ. Monit. 1, 51-56. doi:10.1039/A807778I

Rydin, E. (2000). Potentially Mobile Phosphorus in Lake Erken Sediment. Water Res. 34, 2037-2042. doi:10.1016/S0043-1354(99)00375-9

Sarma, S. S. S., Jiménez-Contreras, J., Fernández, R., Nandini, S., and GarcíaGarcía, G. (2013). Functional Responses and Feeding Rates ofMesocyclops pehpeiensisHu (Copepoda) Fed Different Diets (Rotifers, Cladocerans, Alga and Cyanobacteria). J. Nat. Hist. 47, 841-852. doi:10.1080/ 00222933.2012 .747636

Schindler, D. W., Hecky, R. E., Findlay, D. L., Stainton, M. P., Parker, B. R., Paterson, M. J., et al. (2008). Eutrophication of Lakes Cannot Be Controlled by Reducing Nitrogen Input: Results of a 37-year WholeEcosystem experiment. Proc. Natl. Acad. Sci. 105, 11254-11258. doi:10.1073/pnas.0805108105

SEPA (2002). Analytical Methods for Water and Wastewater Monitor. 4th edn. Beijing: Chinese Environmental Science Press. (in Chinese).

Shatwell, T., and Köhler, J. (2019). Decreased Nitrogen Loading Controls Summer Cyanobacterial Blooms without Promoting Nitrogen-Fixing Taxa: Long-Term Response of a Shallow lake. Limnol. Oceanogr 64, S166-S178. doi:10.1002/ lno. 11002

Shen, J. R., and Du, N. S. (1979). Fauna Sinica, Crustacea, Freshwater Copepoda. Beijing: Science Press. (in Chinese).

Smith, V. H., and Schindler, D. W. (2009). Eutrophication Science: Where Do We Go from Here? Trends Ecol. Evol. 24, 201-207. doi:10.1016/ j.tree.2008.11.009

Søndergaard, M., Bjerring, R., and Jeppesen, E. (2013). Persistent Internal Phosphorus Loading during Summer in Shallow Eutrophic Lakes. Hydrobiologia 710, 95-107. doi:10.1007/s10750-012-1091-3

Søndergaard, M., Jensen, J. P., and Jeppesen, E. (2003). Role of Sediment and Internal Loading of Phosphorus in Shallow Lakes. Hydrobiologia 506-509, 135-145. doi:10.1023/B:HYDR.0000008611.12704.dd

Søndergaard, M., Lauridsen, T. L., Johansson, L. S., and Jeppesen, E. (2017). Nitrogen or Phosphorus Limitation in Lakes and its Impact on Phytoplankton Biomass and Submerged Macrophyte Cover. Hydrobiologia 795, 35-48. doi:10.1007/s10750-017-3110-x

Tong, Y., Wang, M., Peñuelas, J., Liu, X., Paerl, H. W., Elser, J. J., et al. (2020). Improvement in Municipal Wastewater Treatment Alters lake Nitrogen to Phosphorus Ratios in Populated Regions. Proc. Natl. Acad. Sci. USA 117, 11566-11572. doi:10.1073/pnas.1920759117

Trommer, G., Poxleitner, M., Lorenz, P., Bitzilekis, E., Gogaladze, A., Schultes, S., et al. (2017). Altered Food-Web Dynamics under Increased Nitrogen Load in Phosphorus Deficient Lakes. Aquat. Sci. 79, 1009-1021. doi:10.1007/s00027017-0551-2 
Wang, H.-J., Xiao, X.-C., Wang, H.-Z., Li, Y., Yu, Q., Liang, X.-M., et al. (2017). Effects of High Ammonia Concentrations on Three Cyprinid Fish: Acute and Whole-Ecosystem Chronic Tests. Sci. Total Environ. 598, 900-909. doi:10.1016/ j.scitotenv.2017.04.070

Xie, L., Xie, P., Li, S., Tang, H., and Liu, H. (2003). The Low TN:TP Ratio, a Cause or a Result of Microcystis Blooms? Water Res. 37, 2073-2080. doi:10.1016/ S0043-1354(02)00532-8

Xu, H., McCarthy, M. J., Paerl, H. W., Brookes, J. D., Zhu, G., Hall, N. S., et al. (2021). Contributions of External Nutrient Loading and Internal Cycling to Cyanobacterial Bloom Dynamics in Lake Taihu, China: Implications for Nutrient Management. Limnol. Oceanogr. 66, 1492-1509. doi:10.1002/ lno. 11700

Xu, H., Paerl, H. W., Qin, B., Zhu, G., and Gaoa, G. (2010). Nitrogen and Phosphorus Inputs Control Phytoplankton Growth in Eutrophic Lake Taihu, China. Limnol. Oceanogr. 55, 420-432. doi:10.4319/lo.2010.55.1.0420

Zhang, Z. S., and Huang, X. F. (1991). Methods in Freshwater Plankton Study. Beijing: Science Press. (in Chinese).
Conflict of Interest: The authors declare that the research was conducted in the absence of any commercial or financial relationships that could be construed as a potential conflict of interest.

Publisher's Note: All claims expressed in this article are solely those of the authors and do not necessarily represent those of their affiliated organizations, or those of the publisher, the editors and the reviewers. Any product that may be evaluated in this article, or claim that may be made by its manufacturer, is not guaranteed or endorsed by the publisher.

Copyright (C) $2021 \mathrm{He}$, Chen, Du, Li, Liu, Jeppesen and Søndergaard. This is an openaccess article distributed under the terms of the Creative Commons Attribution License (CC BY). The use, distribution or reproduction in other forums is permitted, provided the original author(s) and the copyright owner(s) are credited and that the original publication in this journal is cited, in accordance with accepted academic practice. No use, distribution or reproduction is permitted which does not comply with these terms. 